\title{
THE ANALYSIS OF FACTORS AFFECTING FARMERS' ACCESSIBILITY TOWARDS MARKETS AND ITS RELATION TO FARMERS' BARGAINING POSITION
}

\author{
Rokhman Permadi ${ }^{* 1}$ and Lili Winarti* \\ *) Agribusiness Department, Faculty of Agriculture University of Darwan Ali \\ Jl. A. Yani No 1 Kuala Pembuang Seruyan Regency, Central Kalimantan 74211
}

\begin{abstract}
As the largest banana producing district in Central Kalimantan, currently most of the banana farmers in Seruyan Regency still rely on middleman to collect their crops. There are several factors that allegedly influence farmers in determining the choice of selling their crops to middleman rather than selling directly to the market. The purpose of this research is to analyze the factors that influence the accessibility of farmers to the market and to analyze the relationship between farmer's market accessibility and the bargaining position of farmers toward middleman. The respondents were farmers from the largest producer of banana kepok namely Seruyan Hilir and Seruyan Hilir Timur sub-districts. The method usedwas purposive sampling method and the data was collected in July 2017. The data were analyzed using partial structural equation model (PLS-SEM) with the main variablesare motivation, knowledge, ability to access infrastructure, bond with the middleman, involvement in farmer group, negotiation ability, market accessibility, and bargaining position of farmers. Based on the results of analysis, the knowledge, motivation, ability to access infrastructure and bond with the middleman have significant effect on the accessibility of farmers to the market. The bargaining position of farmers is significantly influenced by the accessibility of farmers to the market.
\end{abstract}

Keywords: market, bargaining position, accessibility, middleman, PLS-SEM

\begin{abstract}
Abstrak: Sebagai kebupaten penghasil pisang terbesar di Kalimantan Tengah, saat ini sebagian besar petani pisang di Kabupaten Seruyan masih mengandalkan pedagang pengumpul sebagai penampung hasil panen mereka. Terdapat beberapa faktor yang diduga mempengaruhi petani dalam menentukan pilihan menjual hasil panen mereka kepada pedagang pengumpul dibanding mereka jual sendiri ke pasar. Tujuan dari penelitian ini adalah untuk menganalisis faktor-faktor yang mempengaruhi aksesibilitas petani terhadap pasar dan untuk menganalisis hubungan antara aksesibilitas pasar dengan posisi tawar petani terhadap pedagang pengumpul. Sampel petani yang dijadikan responden diambil dari wilayah yang merupakan penghasil pisang kepok terbanyak yaitu kecamatan Seruyan Hilir dan Seruyan Hilir Timur menggunakan metode purposive sampling sebanyak 100 sampel an pengambilan data dilakukan pada Bulan Juli 2017. Analisis data menggunakan model persamaan structural parsial (PLS-SEM) dengan variable utama yaitu motivasi, pengetahuan, kemampuan akses sarana prasarana, ikatan dengan pedagang pengumpul, keterlibatan dalam kelompok tani, kemampuan negosiasi, aksesibilitas pasar, dan posisi tawar petani. Berdasarkan hasil analisis diketahui bahwa pengetahuan, akses sarana prasarana, motivasi dan ikatan dengan pedagang pengumpul berpengaruh signifikan terhadap aksesibilitas petani terhadap pasar. Adapun posisi tawar petani secara signifikan dipengaruhi oleh aksesibilitas petani terhadap pasar.
\end{abstract}

Kata kunci: pasar, posisi tawar, aksesibilitas, pedagang pengumpul, PLS-SEM

\footnotetext{
${ }^{1}$ Corresponding author:

Email: rokhmanpermadi@gmail.com
} 


\section{INTRODUCTION}

Since the last few years, Seruyan Regency has been able to contribute as the largest banana production in Central Kalimantan compared to other districts. Based on data of Central Kalimantan fruit production in 2015, banana production contribution of Seruyan Regency is as much as 67,343 quintal. When compared to other districts, the largest production contribution is only 36,834 quintals given by Kotawaringin Barat Regency (Central Kalimantan BPS, 2016).

The high production of bananas in Seruyan Regency does not seem to be proportional to the amount of fruit demand by local consumers. Consequently, the bananas produced from this district are distributed almost mostly to markets outside the city. There are three main destination cities of banana distribution produced by Seruyan Regency; they are Sampit, Palangkaraya, and Banjarmasin.

The relatively long distance between the farmers' lands and the outside market area (closest distance $+170 \mathrm{~km}$ ) makes most farmers unable to reach the market. This condition makes the farmers use intermediary traders as a bridge between farmers and consumers. Permadi (2017) shows that banana kepok farmers in Seruyan District mostly prefer to use distribution channel (Farmer- Middleman-Retailer- Consumers) rather than distribute them directly (Farmers-Consumers).

There are some positive and negative impacts with the existence of marketing agency for farmers. In fact, marketing agencies can help farmers reach consumers especially at locations which are quite far from farmers. On the other hand, the involvement of marketing agencies, as intermediary traders or middlemen (as collectors and retailers traders), will reduce the share received by farmers because there are price differences between farmers and consumers. As Karthikeyan (2016) said that the length of chain from farmers to the consumers can take most of the share that should be accepted by the farmers. According to a research conducted by Permadi (2017), it shows that the consumer and farmer price margin in some distribution channels of banana kapok from Seruyan regency ranges from Rp1,723.2-Rp2,065.6 per kilogram.

Market access is no less important than production issues because a market is a place where the crop production from farmers can be converted into benefits and contributes to the obtained income and prosperity of the farmers' families. Therefore, the ability of farmers to access the market largely determines how much the share will be received by them.

According to Soekartawi (2002), one of the weaknesses of agriculturalsystems in developing countries, including Indonesia, is the lack of attention to the marketing field. Since farmers do not get market information clearly, it finally resulting in the economic opportunity which is quite difficult to achieve. Heinmen (2002) argues that the reason why most rural people cannot improve their lives is because they face difficulties in accessing the market. They can get agricultural input but they do not have the ability to sell to consumers. Magesa et al. (2014) says that due to poor access to agricultural markets, rural farmers have for long relied on traders and other middlemen to gain more profit.

Opening market access is one of the obligations, especially for the government as a stakeholder. So far, the inability of farmers to access the market is only considered as the inability of farmers in accessing transportation facilities. In fact, there are several other factors that may also have big roles in determining the ability of farmers to access markets. Understanding the factors which can influence market access is really important so that the policies taken can be targeted according to actual needs.

According to Gatare et al. (2015), the problem of market access can be considered based on the following three dimensions: physical access to markets; market structure; and lack of skills, information and producer organizations. Physical access in question includes the access to transportation infrastructure. The information included is the knowledge of price and competitors. In relation to producer organizations, Irianto (2008) also states that the formation of farmer groups is one strategy that can be done to help farmers access the market. Suryono et al. (2016) suggests that motivation also has an effect on increasing market access capability.

The ignorance and inability of farmers to reach the consumer market make farmers depends on intermediary traders. This also affects farmers who do not have a strong bargaining position against intermediary traders. Often, banana kapok farmers in Seruyan Regency cannot do much and take for granted the prices set by middlemen. Puspitasari (2015) states that one of the problems which farmers often face in 
Indonesia is that farmers still have a weak bargaining position in negotiating the selling price of their crops. The weak bargaining position of farmers is one of the obstacles in increasing farmers' income.

Based on the background above, the objectives of this research are: 1) to analyze the factors which influence the accessibility of banana Kepok farmers in Seruyan Regency to the market, and 2) to analyze the relationship between market accessibility and the bargaining position of the farmers to the collecting traders.

\section{METHODS}

This research was conducted in Seruyan Regency, precisely in two sub-districts of biggest banana producers; they are Seruyan Hilir and Seruyan Hilir
Timur Sub-district. The samples of farmers taken as respondents, were taken using purposive sampling method in accordance to the criteria of banana kepok farmers as many as 100 samples of farmers. The data collecting activity in respondents was conducted in July 2017.

The variables taken in this study were divided into two groups namely the main variables and characteristic variables. The main variables were the motivation, knowledge, and availability to infrastructure access, bonding with middlemen, activeness in farmer group, negotiation ability, market accessibility, and bargaining position of farmers. Meanwhile, the characteristic variables included were age, banana kapok farming experience, education, and number of family members.

Table 1. The main research variables of the analysis factors which are affecting farmers' accessibility to market and its relation with farmers bargaining position to middlemen.

Latent variables

insists the action to sell the crop to the middlemen

Knowledge: is all of the information owned by farmers about anything related to selling their crops

Ability to access infrastructure: is related to the ability of access to transportation facilities, communications, and information facilities that support marketing activities

Relation with middlemen: is about the mutually binding relationship between farmers and collecting traders or middlemen that are one-sided or two-sided which can hinder the farmers' movement in marketing their agricultural products.

Activity in farmer groups: is the involvement and livelihood of farmers in farmer organizations from the lowest level to the highest level

Negotiation ability: is the ability of farmers in the bargaining process by negotiating to reach agreement of both parties

Market accessibility: is the ability of farmers to access markets and all things related that can facilitate farmers to sell their crops

The bargaining position of farmers: is the ability of farmers to dominate the decision-making process of the crops sale and the ability for not to be easily influenced and or suppressed by others

\begin{tabular}{ll} 
Code & \multicolumn{1}{c}{ Indicators } \\
MO1 & Encouragement because they do not want to bother \\
MO2 & Encouragement to get income quickly \\
MO3 & Encouragement to get income easily \\
PE1 & Knowledge about market target \\
PE2 & Knowledge about market price \\
PE3 & Knowledge about entering market \\
PE4 & Knowledge about transaction method \\
AK1 & Ability to access transportation \\
AK2 & Ability to access communication facility \\
AK3 & Ability to access information \\
IK1 & Availability of agreement with middlemen \\
IK2 & Availability of loan from middlemen \\
IK3 & Availability of pressure from middlemen
\end{tabular}

KL1 Active in the organization of farmer groups

KL2 Active in the marketing organization

KL3 Active in embracing farmers

NG1 Ability to bargain

NG2 Ability to communicate

NG3 Ability to influence middlemen

AS1 Ease in entering the market

AS2 Ease in reaching the market

AS3 Ease in getting market information

AS4 Ease in distributing production to market

PO1 Participating in price determination

PO2 Participating in the determination of purchase method

PO3 Strength in facing the pressure of middlemen 
Data was collected using questionnaires and analyzed using Structural Equation Modeling (SEM) with alternative method of Partial Least Square (PLS) using SmartPLS 3.0 software application. According to Gultom et al. (2015), Abdillah and Jogiyanto (2015), one of the advantages of PLS was its reliability in testing predictive models without basing on assumptions, could be used to predict models with weak grounded theories, and could be used for small sized samples. This study had a framework of model analysis that aimed to facilitate researchers in understanding the purpose of research. Indicators available in any exogenous and endogenous latent variables that were analyzed with reflective indicators as a whole they are presented in Figure 1.

The hypothesis proposed was: H1: motivation had Influenced the market accessibility; H2: knowledge had influenced the market accessibility; H3: Infrastructure access ability had influenced the market accessibility; H4: relation with middlemen had influenced the market accessibility; H5: liveliness in farmer groups had influenced the market accessibility; H6: negotiating ability had influenced the market accessibility; H7: market accessibility had influenced the bargaining position of farmers.

\section{RESULTS}

\section{The Characteristics of Respondents}

Based on the research results on the respondents characteristics who were, still in the range of productive ages, despite there were about $28.00 \%$ of farmers whose aged were more than 50 years. The level of farmers' education was mostly low and there were even $12.00 \%$ of banana kapok farmers who did not complete elementary school (SD). The number of dependents of respondents mostly was more than 2 members in one family. Observing most of the respondent's ages, it was reasonable that the respondents had more than 2 family members despite there were some respondents who only had one or two dependents. Viewed from the experience, farmers apparently had enough experience in banana kapok farming in which there were $62.00 \%$ of farmers had experience more than 10 years.

\section{Farmers' Accessibility toward Market}

Based on the results of the measurement model test using SmartPLS3 application as shown in Figure 2, it shows that there are 2 indicator variables (IK3, and PO3) which have less than 0.6. Loading factor value According to Ghozali and Latan (2015) a tolerable loading factor value for explanatory research must be between $0.6-0.7$, so variable with loading factor less than 0.6 should be eliminated from the model to be able to perform hypothesis testing.

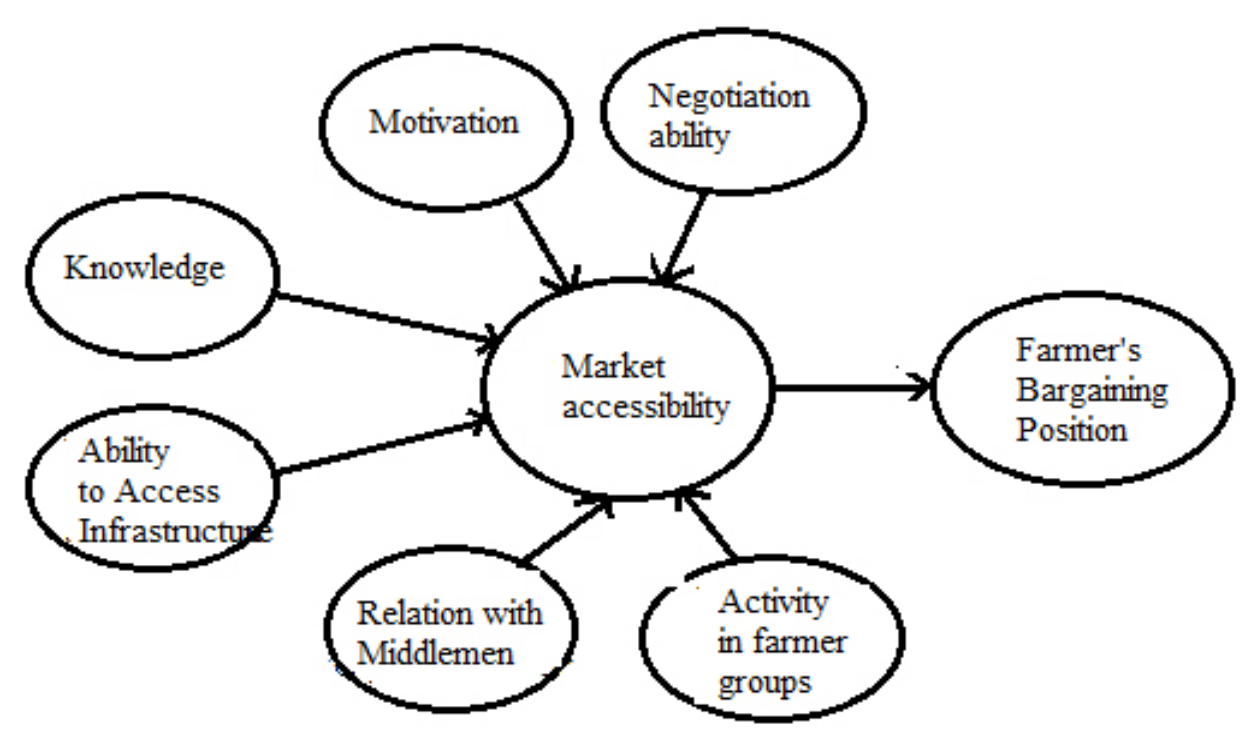

Figure 1. Research framework 
Table 2. The characteristic of banana kepok respondents

\begin{tabular}{llllll}
\hline Characteristic & Number (people) & Percentage (\%) & Characteristic & Number (people) & Percentage (\%) \\
\hline Ages & \multicolumn{5}{c}{ Experience } \\
\hline $19-24$ & 8 & 8.00 & $<5$ & 12 & 12.00 \\
$25-35$ & 27 & 27.00 & $5-<10$ & 26 & 26.00 \\
$36-50$ & 37 & 37.00 & $10-<15$ & 45 & 45.00 \\
$51-65$ & 25 & 25.00 & $15-<20$ & 11 & 11.00 \\
$>65$ & 3 & 3.00 & $>20$ & 6 & 6.00 \\
\hline Education & & & Number of Family Member & \\
\hline No School & 12 & 12.00 & 1 & 1 & 1.00 \\
SD & 43 & 43.00 & 2 & 17 & 17.00 \\
SMP & 17 & 17.00 & 3 & 24 & 24.00 \\
SMA & 24 & 24.00 & 4 & 35 & 35.00 \\
PT & 4 & 4.00 & $>5$ & 23 & 23.00 \\
\hline
\end{tabular}

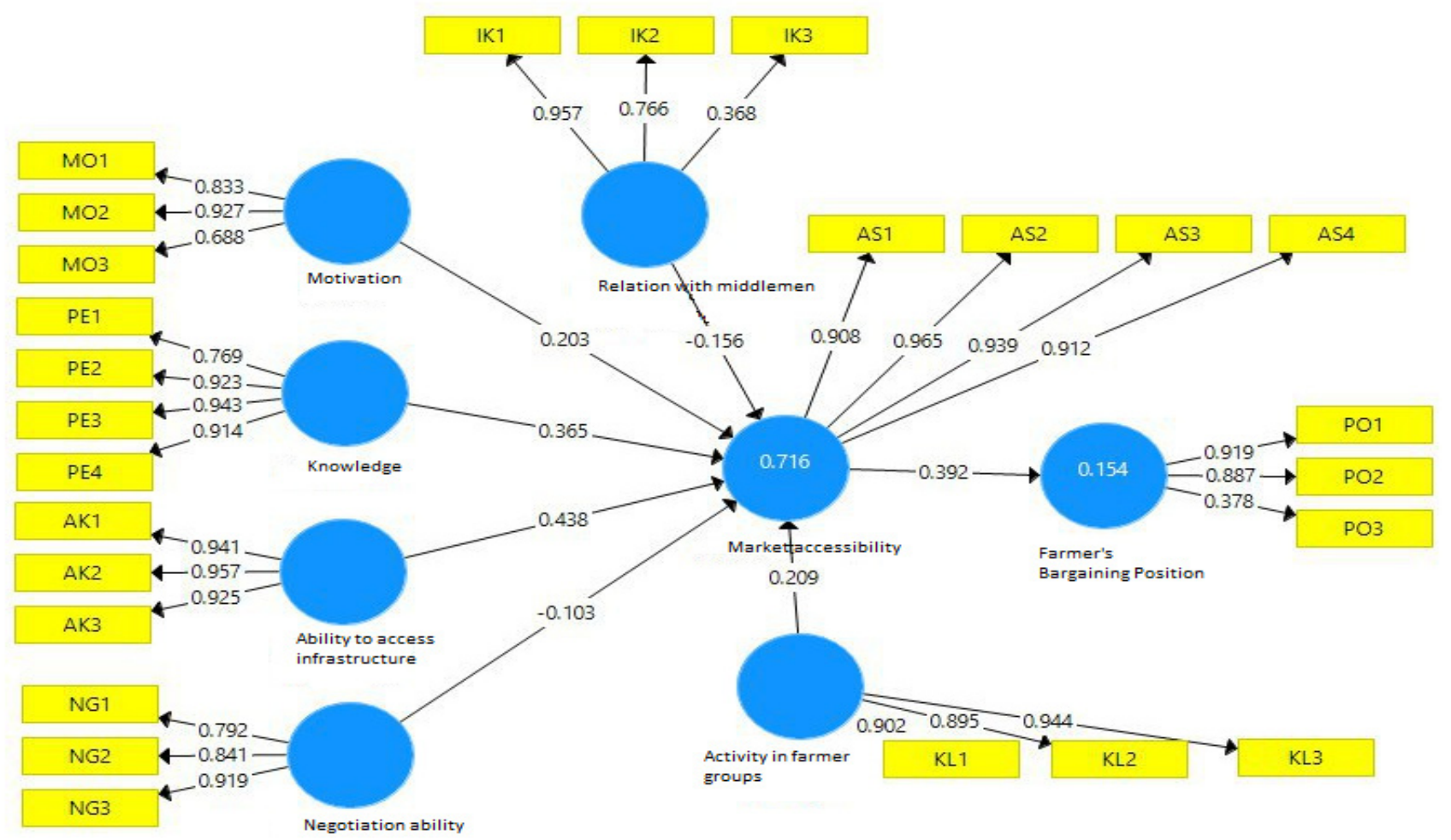

Figure 2. The test result of measurement model

In addition to the loading factor value, convergent validity can also be seen from the Average Variance Extracted (AVE). In this study, the AVE value of each construct is above 0.5 . Therefore, there is no problem of convergent validity in the model being tested. The reliability value using both Cronbachs Alpha and Composite Reliability of each construct exceeds 0.7 so it can be said reliable. Table 3 shows the validity and reliability values for each of the test criteria.

The evaluation of the next structural model was to see the estimated value of the path coefficient including the real effect of a latent construct with other latent constructs. This evaluation would observe the output of SmartPLS 3.0 on bootstrapping to evaluate the direct effect, the T-Statistic value used as the basis for assessing the significant effect of a construct.

After conducted the hypothesis test using Bootstrapping method in SmartPLS 3 application, it was known that the bonding variables with middlemen, motivation, knowledge, ability of infrastructure access had significant impact on farmer accessibility to banana kepok market in Seruyan Regency. Negotiation 
capability had no significant impact on the farmers ability to access the market. This could be seen from the value of $\mathrm{T}$ count of $1.670<$ the $t$ value on the table on $\alpha 0.05$ is 1.96 . Similarly, for the variable of liveliness in farmer groups also did not show significant influence or role because the value of $t$ count was only 1.480.

Farmers with narrow land who had less capital entrusted their agricultural production continuity to middlemen / traders. This resulted that during the post-harvest time of small-scale farmers were unable to determine freely where the farmers might sell their crops (Mahmudah and Harianto, 2014). The descriptive analysis showed that $25 \%$ of banana farmers in Seruyan District were connected to collecting traders or middlemen because of the agreement among them, despite it was not in the form of a written agreement but it became a scourge and fear for the farmers. They worried that in the future the middlemen would no longer take their crops. On the other hand, $14 \%$ of the farmers were also tied to capital loans with collecting traders or middlemen, so farmers also had to sell their crops to them, even though they knew there was a relatively large price difference on the market. The results showed that the relation to middlemen had a significant impact on market accessibility for farmers.

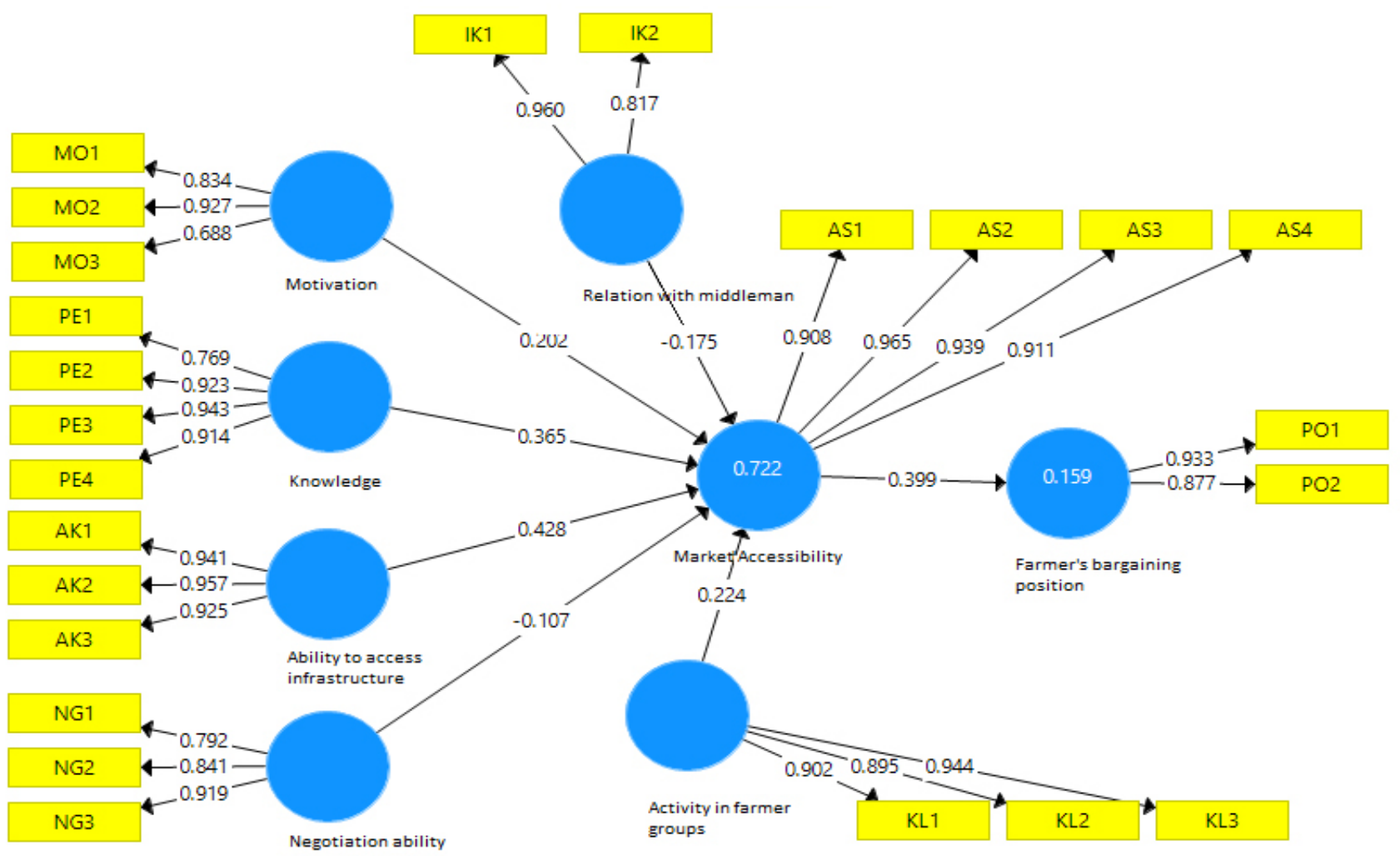

Figure 3. The test result of improved measurement model

Table 3. The analysis result from some criterions of test measurement model

\begin{tabular}{lcccc}
\hline \multicolumn{1}{c}{ Variables } & Cronbachs alpha & Composite realiability & AVE & Root AVE \\
\hline Motivation & 0.804 & 0.860 & 0.676 & 0.822 \\
Knowledge & 0.911 & 0.938 & 0.792 & 0.890 \\
Ability to access infrastructures and facilities & 0.936 & 0.959 & 0.886 & 0.941 \\
Relation with middlemen & 0.767 & 0.885 & 0.794 & 0.891 \\
Activity in farming group & 0.901 & 0.938 & 0.835 & 0.914 \\
Ability to negotiate & 0.816 & 0.888 & 0.726 & 0.852 \\
Market accessibility & 0.949 & 0.963 & 0.867 & 0.931 \\
Bargaining position of farmers & 0.784 & 0.901 & 0.819 & 0.905 \\
\hline
\end{tabular}


The farmers' motivation was also a variable that has a significant influence on market accessibility. There were as many as $79 \%$ of respondents who did not want to be bothered in selling their own crops outside the region. They thought that it was better to use their time to take care of their farms or other necessities rather than to sell their crops out of the area that took a long time because the location was quite far. It was in line with the evidence found by Makura et al. (2004) in Mukwevho and Anim (2014) that there was a negative correlation between farmland distance and market accessed by farmers.

Not all of the farmers had facilities to market their crops including the transportation, communication, or information. A very vital factor was the transportation in which usually only those who had their own vehicle (a pickup van or truck) that could sell their bananas out of the region. Farmers who did not have vehicles or farmers who could not access transportation easily, usually preferred to sell their bananas to collecting traders or middlemen. The result of descriptive analysis showed that $68 \%$ of farmers had difficulties in accessing transportation facilities.

In the modern era where information is widely open, it is actually not too difficult for farmers to access all information related to the market. The Internet network coverage which has been reaching countryside areas can actually be really helpful for farmers to access various information including the market information. The problem that occurred recently was that there were only several farmers who were willing and able to use the available infrastructure facilities in accessing the information to support their farming activities. It could be seen from the respondents where there were only $22 \%$ of respondents who were able to access the available information facilities. Whereas, the ability to access the facilities was not only about accessing transportation facility, but communication and information were also two factors that played a big role in improving market accessibility. The research results by Urquieta and Nadezda (2009) indicated that farmers with cell phones would have better access to market information, which would influence their decisions on the site and price of selling their products. Mobile phones also allowed the farmers to make transactions easily so that the product marketing would be more efficient.
Another variable that also affected the market accessibility was the knowledge variable. The role of knowledge factor was very significant (P-value 0.002) than other influential factors. This was in line with Njeru statement (2015) that the limited knowledge of the market would make it difficult to access the market itself. Farmers who had knowledge of potential buyers, prices, transaction methods, competitors, and how to enter the market would have more easy access to the market than farmers who did not have knowledge about some of those things. Farmers who had no knowledge usually would get difficulties and would usually fail to access the market. Syahza (2003) one of the main problems faced in the marketing of agricultural products was the low quality of human resources (especially farmers). Farmers' guidance tended to cultivation practices and did not lead to marketing practices. This caused the farmer's knowledge about marketing was still low, so the subsystem marketing became very weak and it seemed that the agribusiness system should be well built. Table 4 and Figure 2 show the results of the structural model testing that have been made.

\section{Farmers' Bargaining Position Against Middlemen}

Farmers' bargaining position in this study was the ability of farmers to dominate the decision-making process on the sale of crops and the ability not to be easily influenced and or suppressed by other parties in this case collecting traders or middlemen. Based on the results of the descriptive analysis, there were about $42 \%$ of respondents who said that they were not involved in determining the price of their banana Kepok to middlemen. It meant that farmers just followed the price set by middlemen without bargaining. In the case of determining the method of payment, whether it should be paid directly or paid in the future, there were about $48 \%$ of the farmers who let the middlemen determine the payment method.

If it was seen from how strong the respondents got the influence or pressure from the middlemen, it showed that there were $23 \%$ of farmers who were afraid of the threat from the middlemen and worried if the middlemen would not buy their bananas again in the future. According to Ranjan (2017), one condition that could weaken the bargaining position of farmers was the condition where the intermediary traders or middlemen might leave the farmers to look for other areas that they considered more profitable. 
Table 4. The result of bootstrapping on the structural model between market accessibility and the affecting factors

\begin{tabular}{lccccc}
\hline \multicolumn{1}{c}{ Latent variable } & $\begin{array}{c}\text { Original } \\
\text { Sample }(\mathrm{O})\end{array}$ & $\begin{array}{c}\text { Sample } \\
\text { Mean (M) }\end{array}$ & $\begin{array}{c}\text { Standard } \\
\text { Deviation }\end{array}$ & $\begin{array}{c}\text { T Statistic } \\
(\text { IO/STDEVI) }\end{array}$ & $\begin{array}{c}\text { P } \\
\text { Value }\end{array}$ \\
\hline H3 : Access to Infrastructures $\rightarrow$ Market Accessibility & 0.428 & 0.363 & 0.184 & $2.321^{*}$ & 0.021 \\
H4 : The Relation with Middlemen $\rightarrow$ Market & -0.175 & -0.167 & 0.074 & $2.366^{*}$ & 0.018 \\
Accessibility & & & & & \\
H5 : Activity in Farming Group $\rightarrow$ Market & 0.224 & 0.234 & 0.154 & 1.457 & 0.146 \\
Accessibility & & & & & \\
H6 : Negotiation Ability $\rightarrow$ Market Accessibility & -0.107 & -0.089 & 0.064 & 1.680 & 0.094 \\
H1 : Motivation $\rightarrow$ Market Accessibility & 0.202 & 0.162 & 0.100 & $2.014^{*}$ & 0.045 \\
H2 : Knowledge $\rightarrow$ Market Accessibility & 0.365 & 0.386 & 0.118 & $3.085^{* *}$ & 0.002 \\
Square correlation (R2) & & & & & \\
Market Accessibility=0,722 & & & & & \\
\hline
\end{tabular}

Referring to the data shown in Figure 2, it could be concluded that the bargaining position of the respondent farmers i.e. banana kapok farmers in Seruyan Regency was relatively still weak. It was considered weak because there were still many farmers who just took for granted on what the middlemen determined.in terms of pricing and payment methods. On the other hand, although the number was not too significant, it could indicate the weak bargaining position of farmers.

\section{The Influence of Accessibility on Farmers' Bargaining Position}

The accessibility of farmers toward the market had a very real influence on the bargaining position of farmers with the middlemen with P-value 0.000 (Look at Table 5). If farmers had to sell their crops to middlemen, farmers with high market accessibility would have dominance in pricing and payment method decision with the middlemen. On the otherhand, farmers with low market accessibility would easily be controlled or influenced especially those who were already dependent on middlemen. Danau et al. (2011) suggested that farmers could use several strategies to increase their market power, either using collective strategies or individual strategies. One of the individual strategies that could increase the market power of farmers was by increasing direct production access to consumers. This was in line with the research conducted by Svensson and Yanagizawa (2009) and Shimamoto et al. (2014) who found that better access to market information could improve bargaining position of farmers, so farmers could sell their products at higher prices. Similarly, Yovo (2017) also found that the opening of market access, especially access to price information could improve the bargaining position of farmers.

\section{Managerial implications}

The inability of farmers to access the market was not only caused by the existence of bonds or relation between the farmers and the middlemen or the inability of farmers to access transportation facilities, but there were also other factors that could influence farmers' decision to sell their crops to the middlemen.

The expected managerial implication of this research is that there must be an understanding of marketing management, both on farmers and related stakeholders, so that farmers can enjoy a reasonable part of their farming activities. If it is seen from the factors that have big impacts on the accessibility of farmers to the market, the government or related stakeholders have to pay attention to the steps in order to improve farmers' knowledge on all good information about target market objectives, price, competitors, transaction method and all things related to market.

In addition, in improving farmers' knowledge of the market, it is also important to increase farmers' access to markets by increasing farmers' ability to access existing infrastructure. The availability of transportation, communication, and information infrastructure will not be useful and even become useless if the farmers do not know how to use it.

Training on farmers is not only focusing on improving cultivation skills, but they must also be directed to improve the ability in utilizing the means or facilities to support marketing activities so the farmers can access the market easily. If the farmers have access to large markets, they will have great bargaining power, so they will not be easily deceived and suppressed by the 
middlemen. Although the farmers still use middlemen to market their crops, the dominance of pricing and payment methods is still in their hands, ultimately there will be a reasonable sharing of the benefits from the products produced.

\section{CONCLUSIONS AND RECOMMENDATIONS}

\section{Conclusions}

Based on the objectives and the results of the discussion in this study, it can be concluded that the knowledge variables, access to infrastructure, motivation, and bonding with middlemen have a significant impact on the accessibility of farmers to the market. Meanwhile, the variable of negotiation ability and activeness in farmer group do not have an influence to farmer ability in accessing market. From all influential variables, knowledge variable has the most significant influence toward the market accessibility. Market accessibility has a relation and is a factor that significantly influences the bargaining position of farmers against middlemen. The higher market accessibility by farmers will further strengthen the bargaining position against the middlemen.

\section{Recommendations}

Government as a stakeholder can help farmers improve their market knowledge by providing marketing training and improving access to transportation, communication and information. The easy access to capital is also one of the important things so that the farmers are not bound to the middlemen and it gives the opportunities to the farmers to freely choose where to sell their crops. Further research can be conducted to look at other factors besides market accessibility which may also affect the bargaining position of farmers against collecting traders or middlemen.

\section{REFERENCES}

Abdillah W, Jogiyanto HM. 2015. Partial Least Square (PLS): Alternatif Structural Equation Modeling (SEM) Dalam Penelitian Bisnis. Yogyakarta: Penerbit ANDI.

Central Kalimantan BPS. 2016. Statistik Sayuran dan Buah-Buahan Kalimantan Tengah 2015. Palangkaraya: Central Kalimantan BPS.
Danau A, flament J, Steen DVD. 2011. Choosing the right strategies for increasing farmers' market power. http://www.csa-be.org $\left[\begin{array}{ll}10 & \text { Agustus }\end{array}\right.$ 2017].

Gatare E, Zenon M, Oduor J. 2015. Factors affecting market access in agricultural based projects in Rwanda (a case of home grown school feeding (HGSF) project in Naruguru District). International Journal of Civil Engineering, Construction and Estate Management 3(4): 20 30.

Gultom WST, Yuliati LN, Djohar S. 2015. Pengaruh service quality, product quality dan perceived value terhadap kepuasan dan loyalitas pelanggan industri kayu Perhutani. Jurnal Manajemen \& Agribisnis 13(2): 109-121. https://doi. org/10.17358/JMA.13.2.109.

Ghozali I, Latan H. 2015. Partial Least Square Konsep, Teknik dan Apliaksi Menggunakan Program SmartPLS 3.0 Untuk Penelitian Empiris. Semarang: Badan Penerrbit Universitas Diponegoro.

Heinmen PA 2002. Relationship making in the new economy. Journal of Relationship Marketing 1: 53-61.

Irianto B. 2008. Faktor Penenti Aksesibilitas Petani Ke Pasar. Di Dalam: Seminar Nasional: Inovasi untuk Petani dan Peningkatan Daya Saing Produk Pertanian. Badan Penelitian Dan Pengembangan Pertanian Pusat Penelitian Sosial Ekonomi Pertanian Balai Pengkajian Teknologi Pertanian Karangploso.

Karthikeyan G. 2016. Problems in the marketing of agricultural goods. International Journal of Multidisciplinary Research and Modern Education (IJMRME) II(I): 233-235.

Magesa M.M, Michael K, Ko J. 2014. Access to agricultural market information by Rural Farmers in Tanzania. International Journal of Information and Communication Technology Research 4(7): 264-273.

Mahmudah E, Harianto S. 2014. Bargaining position petani dalam menghadapi tengkulak. Jurnal Paradigma 2(1): 1-5.

Mukwevho R, Anim FDK. 2014. Factors affecting small scale farmers in accessing markets: a case study of cabbage producers in the Vhembe District, Limpopo Province of South Africa. Journal of Human Ecology 48(2): 219-225. https://doi.org /10.1080/09709274.2014.11906791.

Njeru LK. 2015. Influence of youth access to farm 
products markets on their participation in agriculture in Kajiado North Sub-County. International Journal of Agricultural Extension and Rural Development Studies 2(2): 10-18.

Permadi. R. 2017. Analisis efisiensi pemasaran pisang kepok di Kabupaten Seruyan. UNES Journal of Agricultural Scienties 1(1): 120-128.

Puspitasari A.W. 2015. Farmer's Prosperity: How to Increase Farmer's Bargain Power (In Islamic Perspective). Procedia - Social and Behavioral Sciences 2(11). in: 2nd Global Conference on Business and Social Science-2015, GCBSS2015, 17-18 September 2015, Bali. hlm 455 460.

Ranjan R. 2017. Challenges to farm produce marketing: a model of bargaining between farmers and middlemen under risk. Journal of Agricultural and Resource Economics 42(3): 386-405.

Suryono, Panal A.H, Kadji Y, Ilham A. 2016. Effect of training participation, entrepreneurship motivation and market access ability on sales performance of Karawo Craftsmen in Gorontalo Province. International Journal of Business and Management Invention 5(8): 87-93.

Soekartawi. 2002. Prinsip Dasar Manajemen Pemasaran Hasil-hasil Pertanian: Teori dn Aplikasinya. Edisi 1. Cetakan 3. Jakarta: PT. Raja Grafindo Persada.
Syahza A. 2003. Paradigma baru: pemasaran produk pertanian berbasis agribisnis di daerah Riau. Jurnal Ekonomi VIII(1): 1-11.

Svensson J, Yanagizawa D. 2009. Getting prices right: the impact of the market information service in Uganda. Journal of the European Economic Association 7(2-3):435-445. https://doi. org/10.1162/JEEA.2009.7.2-3.435.

Shimamoto D, Yamada H, Gummert M. 2014. The Impact Of Improved Access To Market Information Through Mobile Phones Usage On Selling Prices: Evidence From Rural Areas In Cambodia. Discussion Papers In Economics And Business. Graduate School of Economics and Osaka School of International Public Policy (OSIPP) Osaka University, Toyonaka, Osaka 560-0043, JAPAN.

Urquieta A, Nadezda R. 2009. Effects of access to information on farmer's market channel choice: The Case of Potato in Tiraque Sub-watershed (Cochabamba - Bolivia) [thesis]. Virginia: Faculty of the Virginia Polytechnic Institute and State University.

Yovo K. 2017. Farmer choice, cost of transaction, bargaining power and market information services in Togo. American Journal of Economics 7(5): 230-239. 